\title{
Anthropometry and Ergonomic of Bale Sakenem (Case Study: Central Singapadu Village, Gianyar)
}

\author{
I Wayan Parwata ${ }^{1}$, Anak Agung Gede Oka Wisnumurti ${ }^{2} \&$ Ni Wayan Meidayanti Mustika ${ }^{3}$ \\ ${ }^{1}$ Architecture Department Lecture, Faculty of Engineering, Warmadewa University, Indonesia \\ ${ }^{2}$ Social and Politics Department Lecture, Faculty of Social and Politics, Warmadewa University, Indonesia \\ ${ }^{3}$ Architecture Department Lecture, Faculty of Engineering, Warmadewa University, Indonesia \\ Correspondence: Anak Agung Gede Oka Wisnumurti, Social and Politics Department Lecture, Faculty of Social \\ and Politics, Warmadewa University, Indonesia. E-mail: wisnumurtibali@yahoo.com
}

Received: October 5, 2017

Accepted: October 21, $2017 \quad$ Online Published: November 29, 2017

doi:10.5539/jsd.v10n6p222

URL: https://doi.org/10.5539/jsd.v10n6p222

\begin{abstract}
The Bale Sakenem is one of the buildings located within the Balinese traditional house setting. The development and transformation of the Sakenem bale house are influenced by many factors including high demand, lack of qualified labor, time and work management system resulting in high intervention of Balinese builders (Undagi) on the implementation of the Bale Sakenem development.

This research is an observational research using cross-sectional design. The study measures a sample of "Sakenem" house bale that measures in accordance with anthropometry from homeowners. The sample of the people in this study were Owners/home users who owned the Bale "Sakenem" House that met the inclusion criteria. Samples were randomly selected using cluster random sampling method.

The results of this second-year study showed that $55 \%$ of the sample of people were comfortable with the high suitability of their own "sakenem" bale house structure while $81 \%$ of the sample people felt better comfort against the bale-bale of bale "sakenem" intervention house. The convenience of high listplank also known that as many as $66 \%$ comfort felt from the high listplank house bale "sakenem" intervention. And as many as $52 \%$ chose comfort and suitability of high sakenem "sakenem" saka house height which only slightly comparison with high saka bale "sakenem" control i.e. 48\%. The height of the bale "sakenem" intervention is $76 \mathrm{~cm}$ and the average height from waist to toe of the user of bale "sakenem" house in the village of Singapadu Tengah Gianyar is 75.75 $\mathrm{cm}$ which means that the height of the rod indicates the height which is not ideal and cause inconvenience. The height of bale-bale from bale house "sakenem" is $67 \mathrm{~cm}$ and the average height from waist to tip of user heel bale "sakenem" in the village of Singapadu Tengah Gianyar is $75.75 \mathrm{~cm}$ which can be analyzed that the user can easily rise to the top of bale- bale and create comfort and security. High saka in bale house "sakenem" that is 195 $\mathrm{cm}$ and the average height of bale house owner "sakenem" measured from the tip of the head to the tip of the heel is $165.45 \mathrm{~cm}$ which means that the height of saka is still included in the criteria of comfort.
\end{abstract}

Keywords: Balinese traditional architecture, user anthropometry, convenience

\section{Introduction}

Research on architecture, humans and the environment is an interesting association for continuous research. Similarly, Bali Architecture is closely related to user and the surrounding environment. The result of Parwata (2011) study stated that the development of traditional Balinese home innovation is still based on the anthropometry of the Balinese as the house user, so that the user's suitability and convenience can be felt.

Balinese traditional architecture is built following the layout and spatial arrangement of the house based on Asta Kosala Kosali concept. This concept is one of the concepts used in the technique of arranging a house or a sacred house based on the anatomy of the human body (anthropometry) of its owner. This concept is still used in the construction of traditional houses in Bali in accordance with philosophical, ethical and ritual foundations with due regard to the conception of manifestation, land selection, good days (dewasa ayu) to build a house, and the implementation of the ceremony (yadnya) in its construction. The traditional Balinese house is made up of merajan ('head' area of Balinese houses), bale and courtyard ('body' area of Balinese house), and the front part of house and backyard ('legs' area of Balinese house) (Putra, et al., 2017). 
The size of the existing house in several banjars in the village of Singapadu Tengah, Gianyar is still based on the ownership of AYDs land. This village's wasteland is a piece of land given by the local adat village where its residents live, the size of which is determined by the color level (caste), position and dadia (family groups / communities in the number of families) and can be used for generations according to the prevailing village rules.

Generally, the house "sakenem" is owned by citizens of sudra caste, according to the size of the land given by the adat village. Each of the residents in the land has responsibilities for their customary villages such as: participating in a house and maintaining public houses owned by the village, preparing ceremonies related to customary activities and some activities that must be obeyed by the people. Residents who own houses "sakenem" is certainly the size of the land is narrower than people who have houses "sakutus" or "sakaroras". And if forced to build the house "sakutus" or "sakaroras" in the yard, then the layout and spatial arrangement of the house more crowded, uncomfortable and even shifting values on layout and spatial arrangement in Balinese architecture.

\section{Literature Review}

\subsection{Bale Dangin House Form}

Bale Dangin is a house whose position is located on the east side of a traditional residence in Bali. Bale Dangin house form of rectangular or rectangular. Bale Dangin house consisting of 6 poles (Saka) is called Bale "Sakenem".

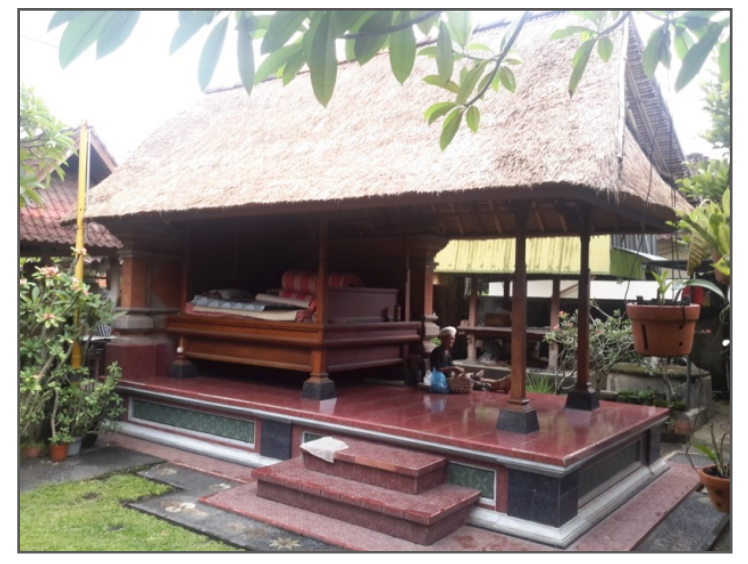

Figure 1. Bale "Sakenem" House in Banjar Negari, Singapadu Tengah Village, Gianyar

Source: Observations (2015)

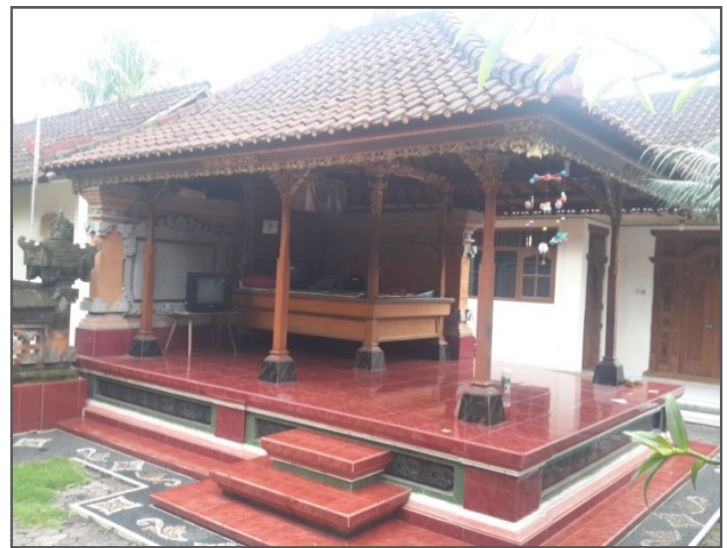

Figure 2. Bale "Sakutus" House in Banjar Negari, Singapadu Tengah Village, Gianyar

Source: Observations (2015)

Because the house Bale "Sakenem" is located in the eastern (dangin) natah umah, so this house is also often called Bale Dangin or Bale Gede. The main function of this house is the place of the ceremony. In some homes in the village of Singapadu Tengah, bale house "Sakenem" in addition functioned as a place of ceremony manusa yadnya, it is also used as a bed, especially for older family members like grandparents. The number of household members, the family income, and household type influenced the transformation of Bale Sakenem house (Sueca, 2003).

Based on observations in the village of Singapadu Tengah, often the existing Bale Sakenem house has not considered the size (anthropometry) of the user. The result is the size of the house is too high, so users feel less safe and comfortable when using. The high house of Bale Sakenem can be seen from the size of stairs, Bataran, Bale-bale and pole (Saka). 


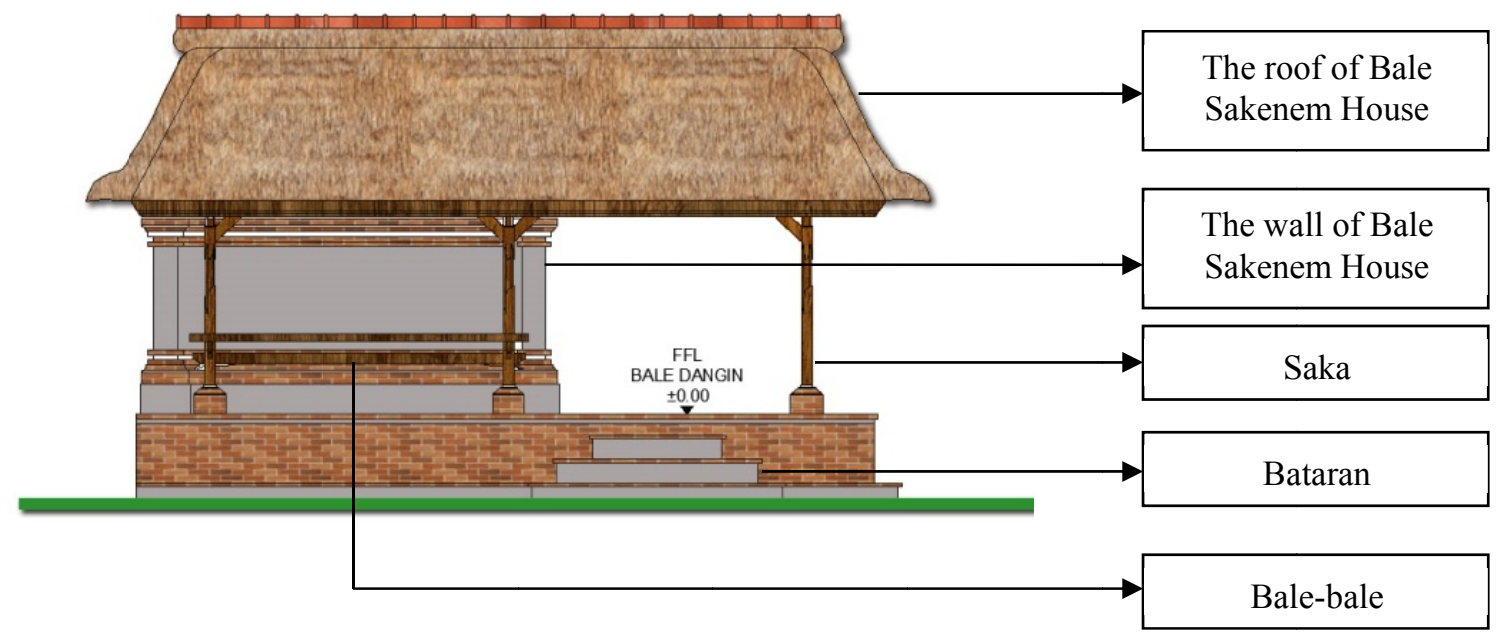

Figure 3. The Parts of Bale Sakenem House

Use of anthropometric sizes from Bale "Sakenem" users/house owners well, will provide more convenient and representative results for users/owners (Parwata, 2011). This measure is expected to be used as an example to other users if it has the same anthropometric size. The flexibility of this size is the basic standard of other Bale "Sakenem" house sizes.

\subsection{House Structure of Bale "Sakenem"}

Bale house "Sakenem" has the same concept with other Balinese traditional house, that is in its making using Tri Angga concept that has three parts as follows (Rikyana, 2016):

a. The Legs section called the Bataran, which is the lower lying rock, is made of stone pairs.
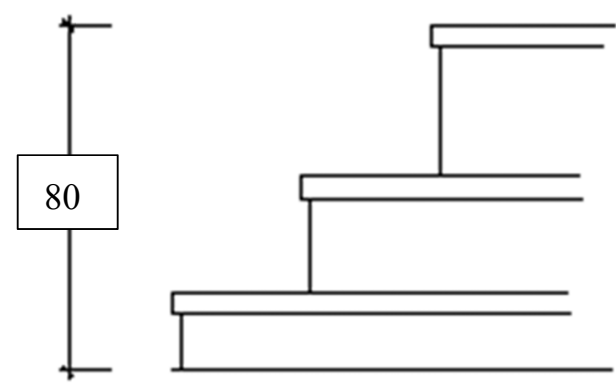

Figure 4. Bataran of Bale Sakenem House

b. Parts of the Body called Saka and Bale-bale are part of the bale house "Sakenem" which is bound by the symbol sineb which is the body of the house bale "Sakenem". 

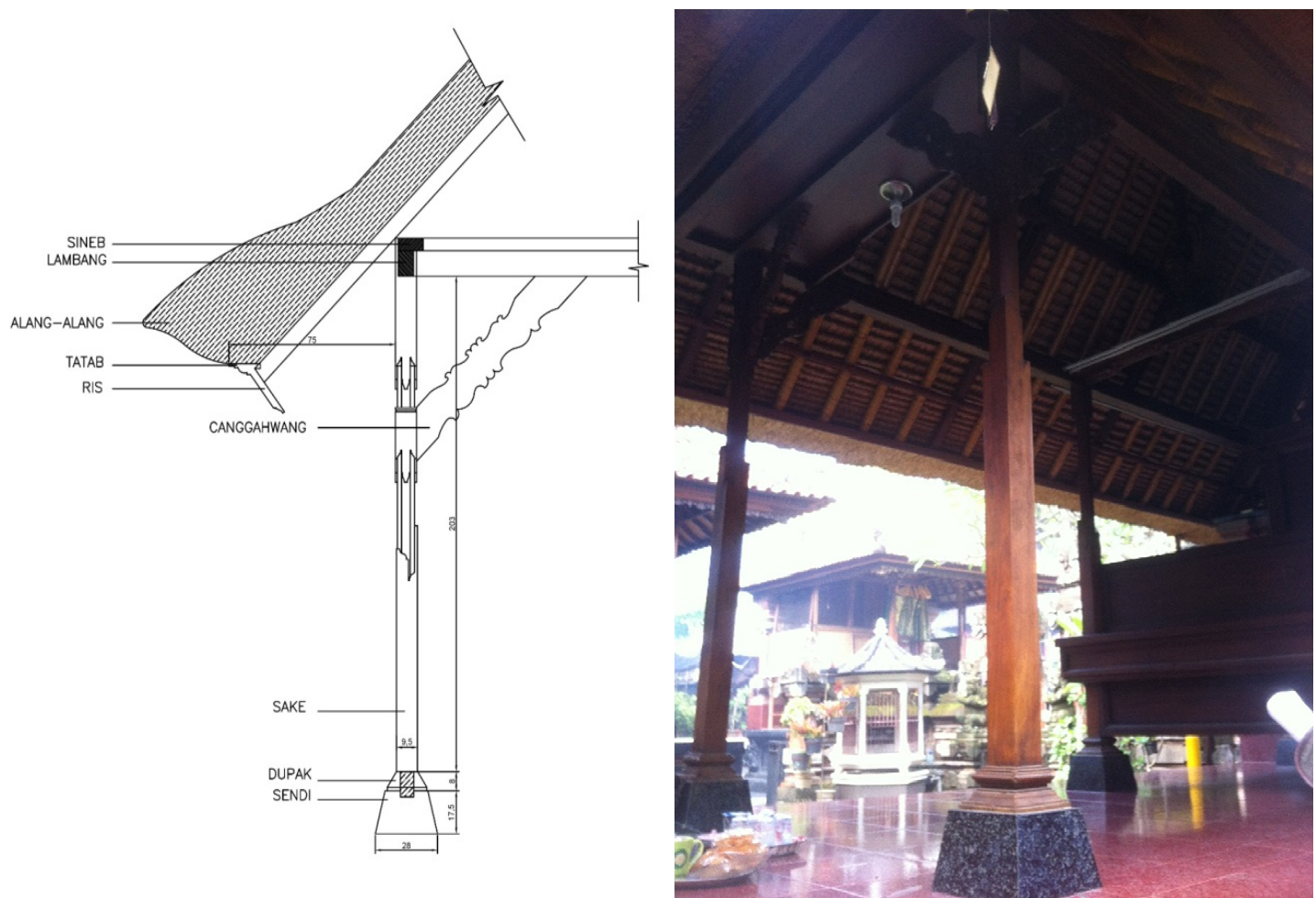

Figure 5. Saka of Bali Sakenem House
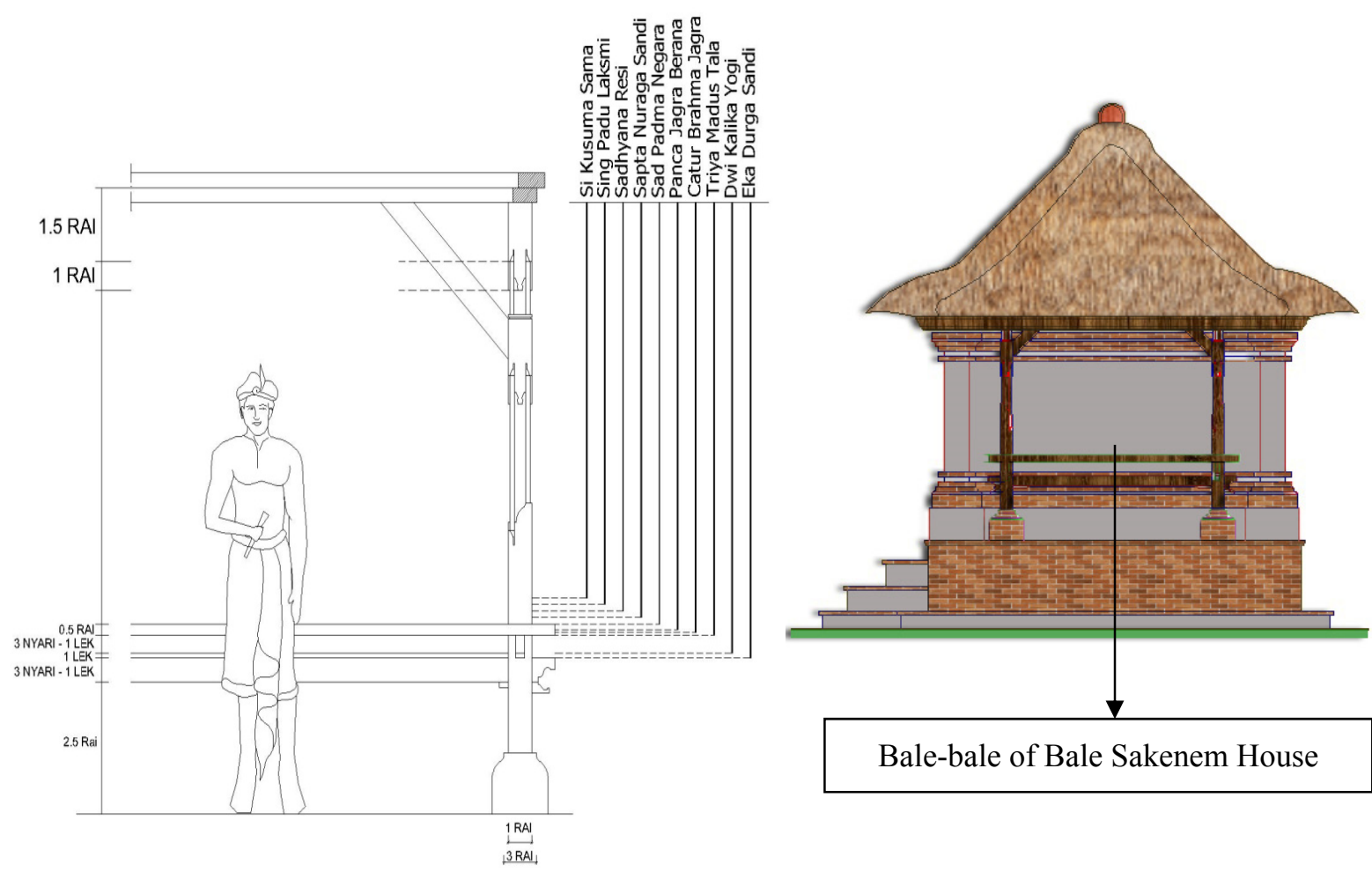

Figure 6. Bale-bale of Bale Sakenem House

c. Head section is the top of the house bale "Sakenem" from sineb to the roof of the house. 


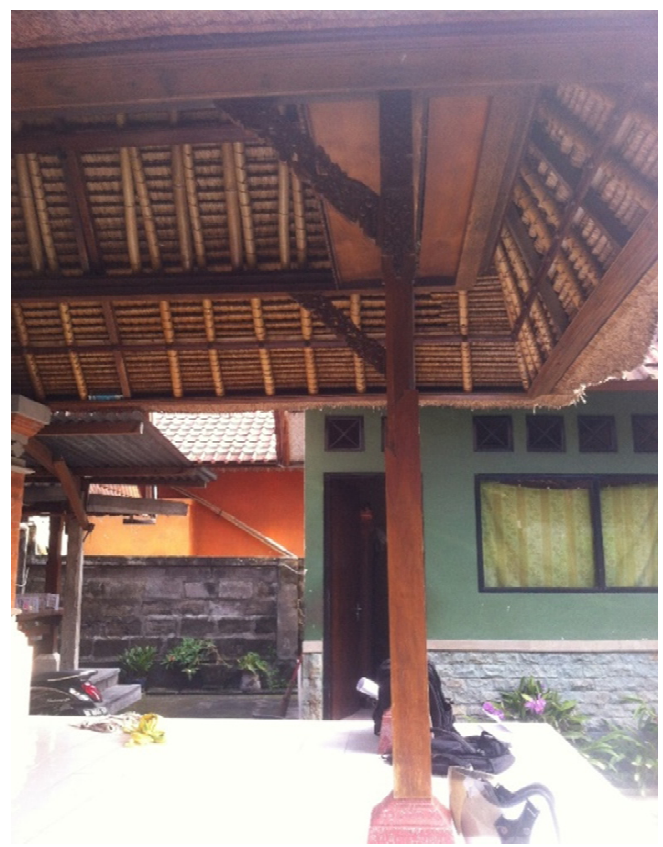

Figure 7. The roof of Bale Sakenem House

\subsection{Anthropometry and Applications in Bale House "Sakenem"}

Anthropometry comes from the word "anthro" which means man and "metri" which means size. Definitively anthropometry is a study related to the measurement of the dimensions of the human body. Anthropometry plays an important role in the field of industrial design, clothing design, ergonomics, and architecture. In these fields, statistical data on the distribution of body dimensions of a population are required to produce the optimal product. Changes in everyday lifestyles, nutrients and ethnic composition of society can make changes in the distribution of body size.

Anthropometry with physical characteristics of the human body, shape and strength and application of the data for handling design problems. Anthropometry can also be used as ergonomic considerations that require human interaction. The anthropometric data that have been obtained can be applied to the case (Wignjosoebroto, 2003):

1) Work area design (workstation, car interior)

2) Designing work equipment (machine, tooling)

3) Designing consumer products (clothes, chairs, computer desk)

4) Designing the physical work environment

\section{Method}

This research is an observational research using cross-sectional design. The study was conducted by retrospective observational i.e. assessing the factors that could influence the anthropometry of Bale House "Sakenem". Having known factors that could affect the anthropometry of Bale House "Sakenem", the study continued by conducting pre-experimental research with one group pre-post-test design approach. The design of one group proposes test design is a design that reveals causal relationships by involving a group of subjects from a sample. Subject groups will be observed prior to intervention and observed again after intervention (Nursalam, 2008). In this study, researchers measured bale samples of "Sakenem" houses that were in accordance with the anthropometry of homeowners. The sample of the people in this study were Owners/home users who owned the Bale "Sakenem" House that met the inclusion criteria. Samples were randomly selected using cluster random sampling method. This sampling technique is carried out on a sampling unit, where the sampling unit consists of one cluster. Each item (individual) within the selected group will be taken as a sample. The sample of the selected person assesses the convenience of the "Sakenem" house bale sample that measures in accordance with the anthropometry of its users. 


\section{Result and Discussion}

\subsection{Level of Comfort House Bale "Sakenem" Intervention and Control}

Comfort Level of House Bale "Sakenem" assessed by research instrument that is questionnaire of comfort level appraisal. This study analyzed the comparison of bale "sakenem" house comfort by requesting a sample of people comparing the comfort level of bale house "sakenem" with bale house "sakenem" hers. And after the comfort level is felt by a sample of people then the next sample of people asked to compare the comfort level of bale house "sakenem" intervention with bale house "sakenem" own.

Based on the assessment of the comfort level of bale house "sakenem", the following results are obtained:

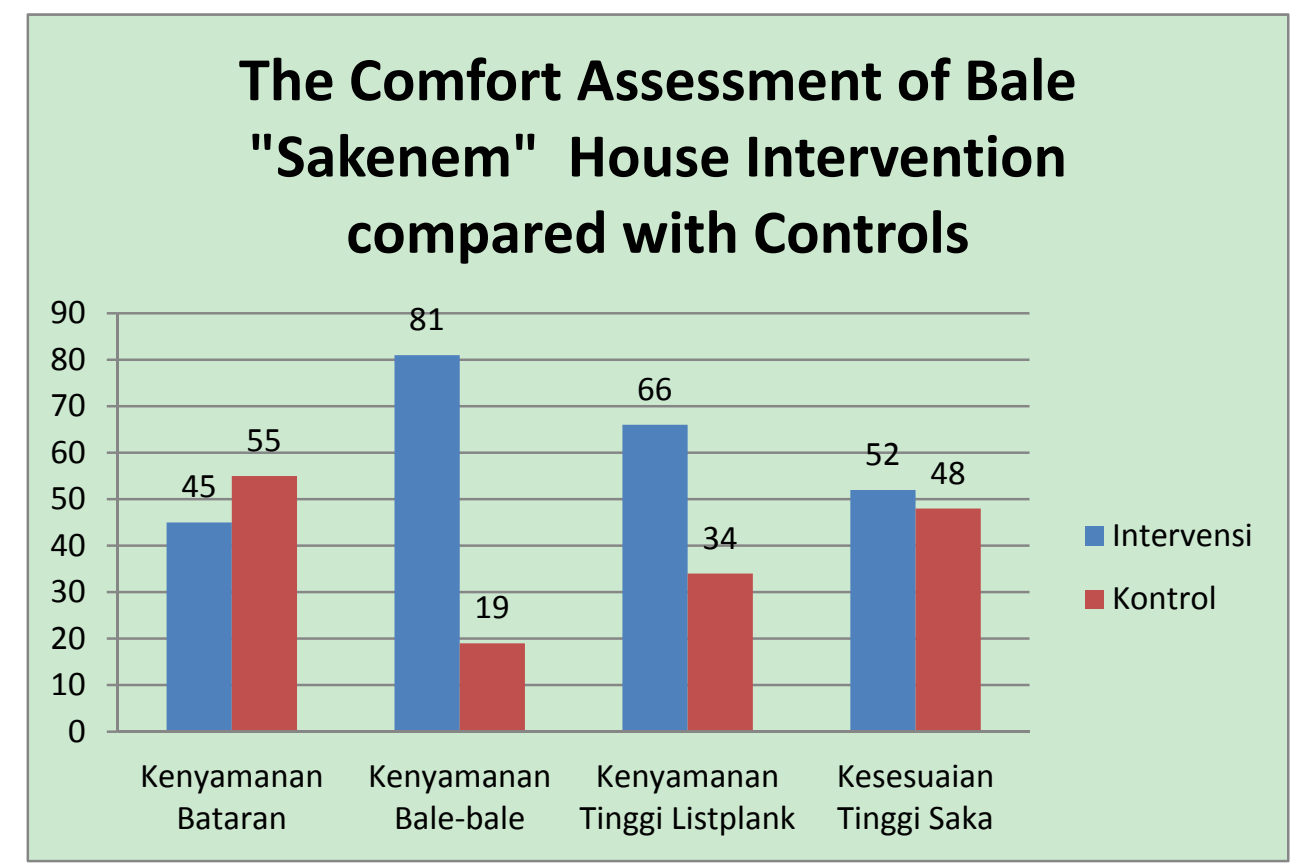

Figure 8. The Chart that Describes about The Comfort Assessment of Bale "Sakenem" House Intervention compared with Controls

Based on the diagram above, it can be seen that as many as 55\% are more comfortable with the high suitability of their own "sakenem" bale house. High-impact comforts are assessed by assessing whether they are comfortable when they are grounded and when they go up and down through the rocks. The bale of the bale house "sakenem" intervention tends to be less comfortable when compared to the bale of the bale house "sakenem" belonging to a sample of people.

From the figure above, it can also be seen that as many as $81 \%$ of the sample people feel better comfort against the bale-bale of the bale house "sakenem" intervention. Measurement of comfort to the bale-bale done by doing up and down activities and sitting on the bale-bale.

The convenience of high listplank can also be known based on the picture above, that is as much as $66 \%$ comfort felt from the high listplank house bale "sakenem" intervention. The convenience of high listplank is known by grabbing listplank and feel the comfort of high listplank. In the measurement of comfort is also seen whether the sample of people has to tiptoe in reaching listplank. If the sample of people able to reach listplank without tiptoe, then it can be categorized that the listplank is appropriate and comfortable.

Based on the figure above can be seen also that as much as $52 \%$ who chose the comfort and suitability of high saka house bale "sakenem" intervention that only slightly comparison with high saka house bale "sakenem" control that is $48 \%$. Comfort and suitability of saka height are measured by user's "rai" and compared to the height of the saka. Another way to measure the comfort of saka height is by measuring the height of the sample of the person and then compared with the height of saka.

\subsection{Comparative Analysis of Antecomputer Size of Bale House Users "Sakenem" with Bale House "Sakenem" Intervention}

Anthropometric measurements can be used as ergonomic considerations that require human interaction. House 
bale "sakenem" in Hindu religious activities is needed for religious ceremonies. This bale "sakenem" house functioned as a place for performing religious ceremonies (manusa yadnya and pitra yadnya), for a place of musyawarah for family, and as a bed or resting place for an old family member. Therefore, the convenience of bale house "sakenem" is very important created to provide a sense of comfort and safety to parents and family members when doing activities in bale house "sakenem". Comfort can be seen from the comfort of climbing the stairs of the house (rock), comfort while climbing into bed from bale house "sakenem" (bale-bale), and comfort and flexibility while in bale house "sakenem" which can be measured through the height of saka.

The result of anthropometric measurement of bale house user "sakenem" which is then analyzed and compared with the height of the rock can be seen in the following figure.

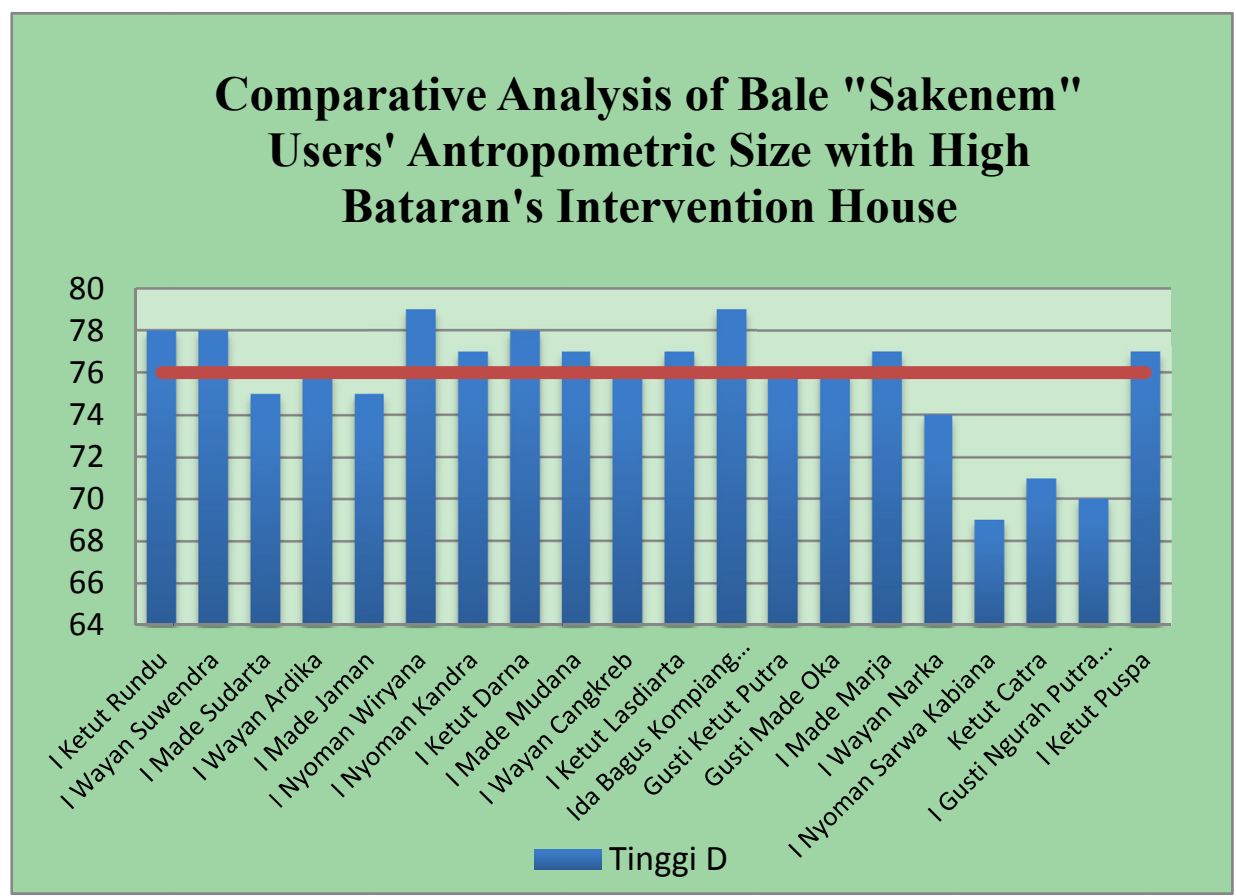

Figure 9. The Chart that Describes Comparative Analysis of Bale "Sakenem" Users' Antropometric Size with High Bataran's Intervention House

Based on the picture above 4, it can be seen that the height of bale from bale house "sakenem" intervention is 76 $\mathrm{cm}$. After user anthropometric measurement, it is known that the average height from waist to toe of the user of bale "sakenem" house in the village of Singapadu Tengah Gianyar is $75.75 \mathrm{~cm}$. With the user's high averages, the height of the rod indicates an unfavorable height and inconvenience when the user goes up and sits on the rock. This is due to excessively high temperatures and causes discomfort while sitting on the rocks. This is also in accordance with the results of high-comfort measurements where as many as 55\% chose the height of the bale house's "sakenem" house of a more comfortable person compared to the bale house "sakenem" intervention. Measurement analyzes of anthropometric measures of users were also compared with high bale-bale of the bale house "sakenem" intervention. The results of the comparison can be seen as follows. 


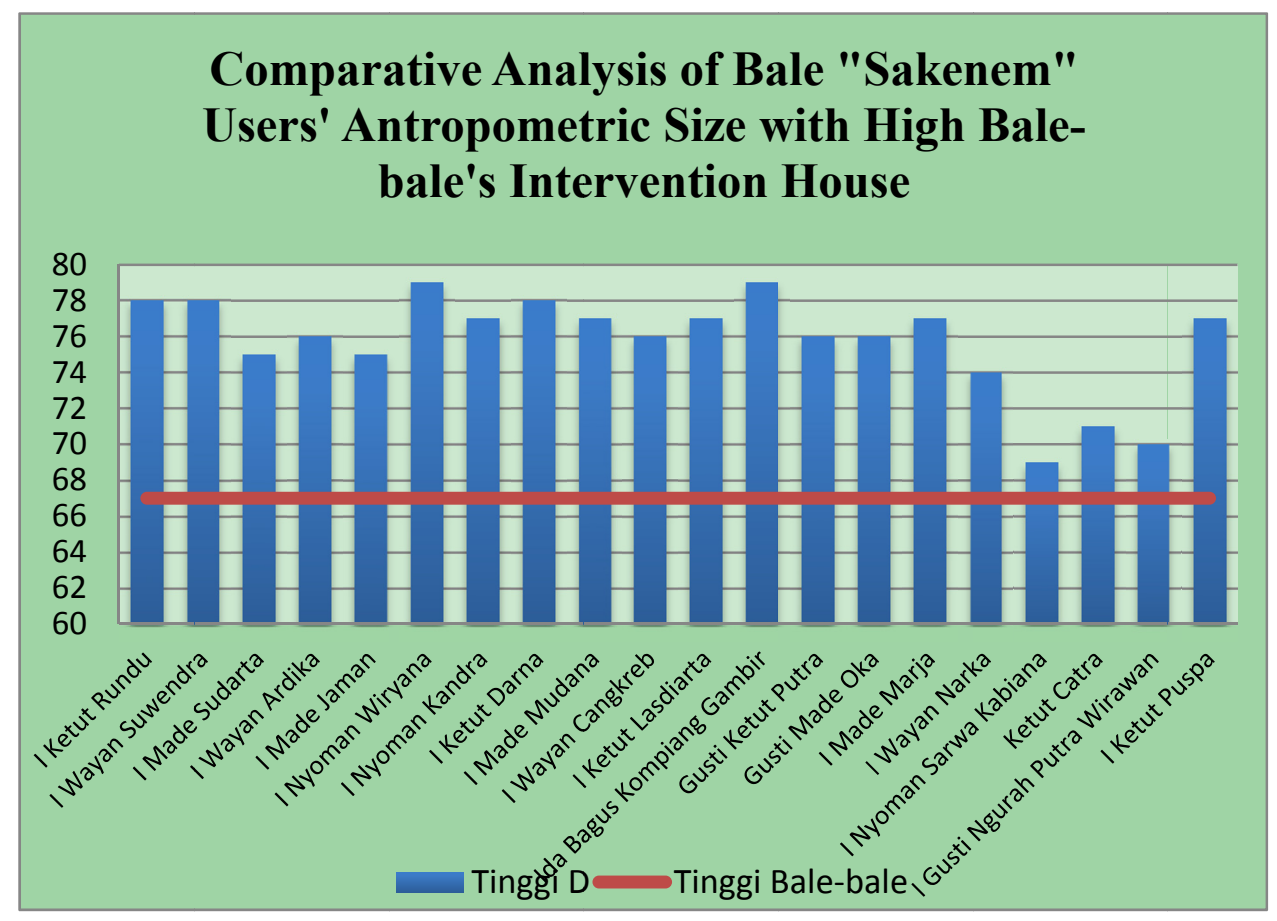

Figure 10. The Chart that Describes Comparative Analysis of Bale "Sakenem" Users' Antropometric Size with High Bale-bale's Intervention House

Based on the picture above, it can be seen that the height of bale-bale from bale house "sakenem" is $67 \mathrm{~cm}$. The measurement results showed that the average height from waist to heel end user bale "sakenem" in the village of Singapadu Tengah Gianyar is $75.75 \mathrm{~cm}$. From the results of the comparison, it can be seen that the height of bale-bale of the house intervention meets the criteria of comfort. Viewed from the height of bale-bale bale house "sakenem" intervention that is $67 \mathrm{~cm}$ and compared with the average height from waist to tip heel user bale "sakenem" in the village Singapadu Tengah Gianyar is $75.75 \mathrm{~cm}$, can be analyzed that the user can easily rise to the top bale-bale. The ease of activities up and down in the bale-bale creates the comfort and security to use bale-bale as a place of traditional ceremonies. Based on the high comfort rating of bale-bale bale house "sakenem" intervention is also appropriate ie as much as $81 \%$ sample people choose high bale-bale home intervention much more convenient and easy in doing activities.

The height measurement of saka in bale house "sakenem" intervention was also analyzed and compared with anthropometric measurement results of users. An anthropometric measure used is the size of the height from head to heel. The result of comparison analysis of anthropometric measure of users with high saka bale "sakenem" intervention can be seen as follows. 


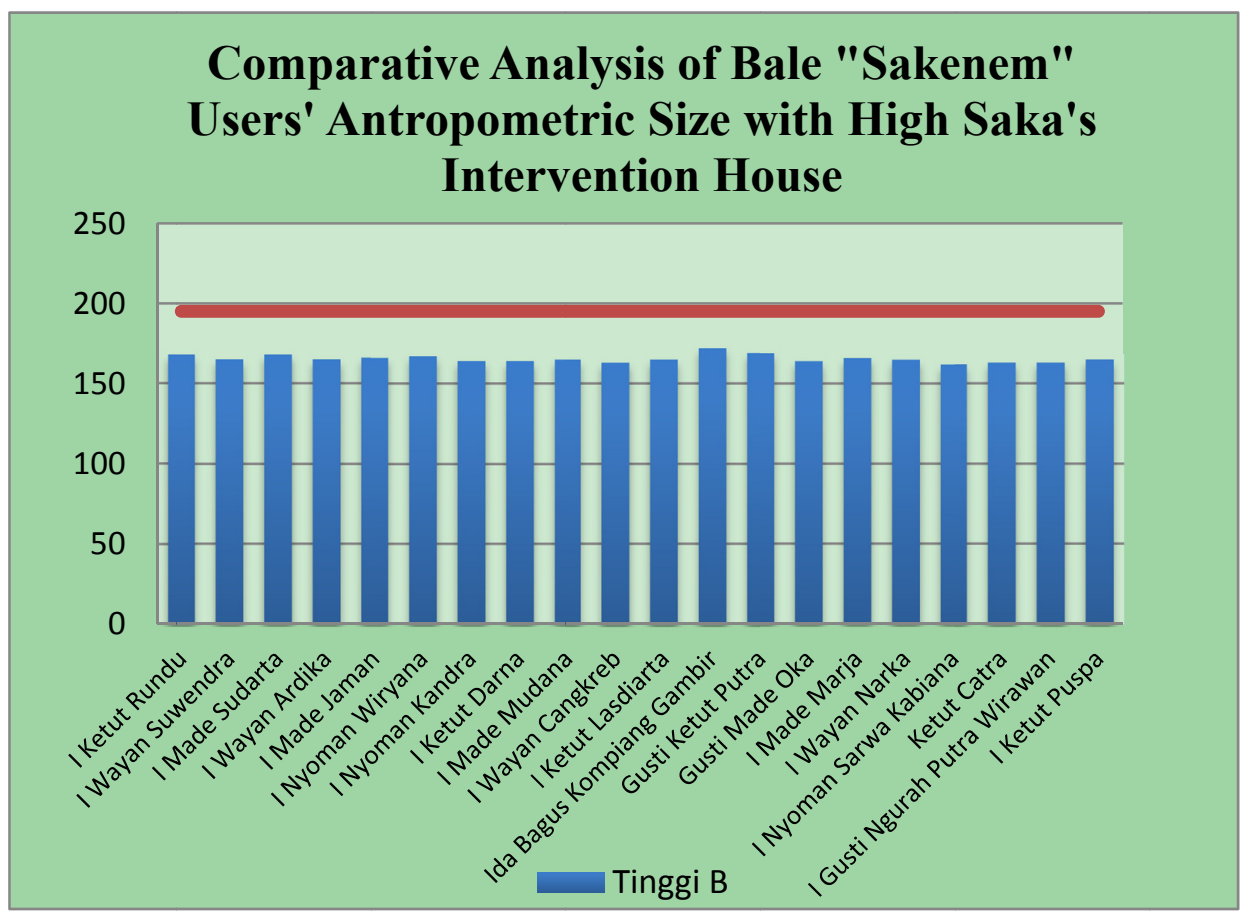

Figure 11. The Chart that Describes Comparative Analysis of Bale "Sakenem" Users' Antropometric Size with High Saka's Intervention House

Based on the picture above 6, it can be seen that the height of saka on bale house "sakenem" is $195 \mathrm{~cm}$. The average height of bale house owner "sakenem" measured from head to heel is $165.45 \mathrm{~cm}$. These results indicate that the height of saka is still included in the criteria of comfort. This is also in accordance with a study by Parwata (2016), which states that the maximum tolerable saka is $209 \mathrm{~cm}$. The results of this analysis are also in accordance with conformity and comfort assessment of high saka where as much as $52 \%$ of sample people choose high saka bale house "sakenem" intervention is in accordance with high and comfort.

\section{Conclusion}

This study analyzed and compared the bale house "sakenem" intervention with bale house "sakenem" control. The results of measurement and analysis of the high variables Saka, high Bataran, and high Bale-bale can be summarized as follows:

1) As many as $55 \%$ of the sample people feel comfortable with the high suitability of their own "sakenem" bale house while $81 \%$ of the sample people feel better comforts against the bale-bale of bale "sakenem" intervention house. The convenience of high listplank also known that as many as $66 \%$ comfort felt from the high listplank house bale "sakenem" intervention. And as many as 52\% chose comfort and suitability of high sakenem "sakenem" saka house height which only slightly comparison with high saka bale "sakenem" control ie $48 \%$.

2) The height of the bale "sakenem" intervention is $76 \mathrm{~cm}$ and the average height from waist to toe of the user of bale house "sakenem" in the village of Singapadu Tengah Gianyar is $75.75 \mathrm{~cm}$. which means that the height of the rod shows an unhealthy height and causes discomfort.

3) The bale-bale height of the bale "sakenem" house is $67 \mathrm{~cm}$ and the average height of bale "sakenem" users in the village of Singapadu Tengah Gianyar is $75.75 \mathrm{~cm}$ which can be analyzed that the user can easily rise to the top of the bale and create comfort and security.

4) The height of saka in bale house "sakenem" that is $195 \mathrm{~cm}$ and the average height of bale house owner "sakenem" measured from the tip of the head to the tip of the heel is $165.45 \mathrm{~cm}$ which means that the height of saka is still included in the criteria of comfort.

5) The positive sides of user anthropometry applied to Bale Sakenem are Bale Sakenem house can be utilized optimally, users do not feel difficult when climbing to the rocks, sit and sleep in Bale-bale and when reaching langki (dioverstek). Users of Bale Sakenem houses are more comfortable because the size and 
dimensions of houses (staircase, bale-bale, high saka, and overstek) follow anthropometry and user comfort. Bale Sakenem house is more proportional to the size of the user or owner. Bale Sakenem house has more positive vibration. The negative sides are Undagi (builder of Bale Sakenem) should spend time carefully measuring the anthropometry of users or house owners.

\section{References}

Acwin, D. N. K. (2008). Artikel "Perumahan dan Pemukiman Tradisional Bali". Denpasar.

Acwin, D. N. K. (2010). Arsitektur Rumah Tradisional Bali. Denpasar: Udayana University Press.

Bija, I. M. (2012). Asta Kosala-Kosali Asta Bumi, Pustaka Bali Post: Denpasar.

Gelebet, I. N. (1986). Arsitektur Tradisional Daerah Bali. Denpasar: Departemen Pendidikan dan Kebudayaan Proyek Inventarisasi dan Dokumentasi Kebudayaan Daerah.

Ishikawa, K. (2015). Guide to Quality Control (Japanese): Gemba No QC Shuho (1968) by JUSE Press, Ltd., Tokyo. Retrieved from www//:id.wikipedia.org/wiki/Diagram_Ishikawa diunduh

Mulyati, M. I. (2012). Prinsip Ergonomis Dalam Produk dan Sikap Kerja. Retrieved from http://www.google.co.id/\#q=TATA+ATURAN+PEMBANGUNAN+RUMAH+TRADISIONAL+BALI\&hl $=$ id\&prmd=imvns\&ei=2YErT_GZOpGrrAefodHUDA\&start=20\&sa=N\&bav=on

Notoatmodjo, S. (2005). Pendidikan dan Perilaku Kesehatan. Jakarta: Rineka Cipta.

Nursalam. (2008). Konsep dan Penerapan Metodologi Penelitian Ilmu Keperawatan, Editor: Tim Editor Salemba Medika, Jakarta: Salemba Medika.

Parwata, I. W. (2009a). Ergonomic Intervention by Ventilation and Windows Remodeling Increases Comfort of Occupants of Houses Type 36/120 in Nuansa Kori Housing Sading Mengwi Badung, Majalah Ilmu Faal Indonesia, Vol. 9, No. 1.

Parwata, I. W. (2009b). HUMANISASI: Kearifan \& Harmoni Ruang Masyarakat Bali, Editor: Iwan Sudradjat, Yayasan Tri Hita Karana Bali: Denpasar.

Parwata, I. W. (2009c). Konsep Rancang Bangun dalam Arsitektur, Yayasan Tri Hita Karana Bali: Denpasar.

Parwata, I. W. (2011a). Rumah Tinggal Tradisional Bali dari Aspek Budaya dan Antropometri. Jurnal Mudra, 26(1), 95-106.

Parwata, I. W. (2011b). Merancang Rumah Ergonomis: Implementasi Prinsip-prinsip Ergonomi dalam Rancang Bangun Rumah Tinggal, Editor: Prof. Ida Bagus Adnyana Manuaba, Yayasan Tri Hita Karana Bali: Denpasar.

Parwata, I. W., Wisnumurti, A. A. Gede Oka, Meidayanti, M., Ni Wayan. (2016). Implementation of User Anthopometry Bale "sakenem" Houses based on Height Bataran and Height Bale-bale in Singapadu Tengah Village, Gianyar., International Series on Integrated Science and Technology (INSIST) Journal, Volume 1, No. 1 (2016), Universitas Lampung: Bandar Lampung: 2016.

Putra, I. D. G. A. D., Lozanovska, M., \& Fuller, R. J. (2017). Methodology to Evaluate The Transformat ion of Traditional Balinese Houses as A Consequence of Tourism (pp. 83-100). Cambridge: International Journal of Architectural Reseach. Retrieved from https://search.proquest.com/printviewfile?accountid=179919

Rikyana, I. G. (2016). Bale Dangin Sakenem, Tugas Studio Arsitektur Tradisional Bali, Universitas Dwijendra: Denpasar.

Suardana, Gde, I Nyoman. (2015). Rupa Nir Rupa Arsitektur Bali, Widya Pataka: Bali.

Sueca, N. P. (2003). Housing Transformation: Improving environment and developing culture in Bali. (unpublished $\mathrm{PhD}$ thesis). University of Newcastle upon Tyne.

Widana, I. B. G. (2011). Dharmaning Hasta Kosali Arsitektur Tradisional Bali, Penerbit: Dharma Pura: Denpasar.

Wignjosoebroto, S. (2008). Ergonomi, Studi Gerak dan Waktu: Teknik Analisis untuk Peningkatan Produktivitas Kerja, Edisi Keempat, Cetakan Keempat, Guna Widya: Surabaya.

Witana, I. N. (1973). Asta Kosala Kosali: Ketentuan Adat Tradisional mengenai Bangunan Bali, House Information Centre, Dinas Pekerjaan Umum Prop. Bali. 


\section{Appendix}

I. Identity Information

Name

Address

HP

Occupation

II. Bale Sakenem Building Comfort Rating

1. Is the height of the stairs on the bale Sakenem (intervention) comfortable to be grounded when compared to the your house (Respondent's House)?
a. Very Comfortable
b. Comfortable
c. Less Comfortable
d. Uncomfortable

2. When you sit in Bataran of Bale Sakenem Building, What do you feel ?
a. Very Comfortable
b. Comfortable
c. Less Comfortable
d. Uncomfortable

3. When you want to sit on the Bale-bale of Bale Sakenem building, you feel :
a. Very Easy
b. Easy
c. Difficult
d. Very Difficult

4. What do you feel when you reach the listplank of Bale Sakenem Building ?
a. Very Easy
b. Easy
c. Difficult
d. Very Difficult

5. Do you need to lower your head to climb to the top of the bale?
a. Yes, I do.
b. No, I don't.

Reason.......

6. Are you able to reach the roof of the bale by raising the hand up?
a. Yes
b. No

Reason.......

7. In your opinion, when rain, are the rain water will enter the bale Sakenem?

a. Yes

b. No 
Reason.......

8. Do you feel comfortable when you do activites in the Bale Sakenem Building ?

a. Yes, I do

b. No, I don't

Reason.......

9. When you go up the Bale-bale, What do you feel ?
a. $\quad$ Easy (sitting without help)
b. Difficult (by holding saka when go to Bale-bale)

\section{Copyrights}

Copyright for this article is retained by the author(s), with first publication rights granted to the journal.

This is an open-access article distributed under the terms and conditions of the Creative Commons Attribution license (http://creativecommons.org/licenses/by/4.0/). 